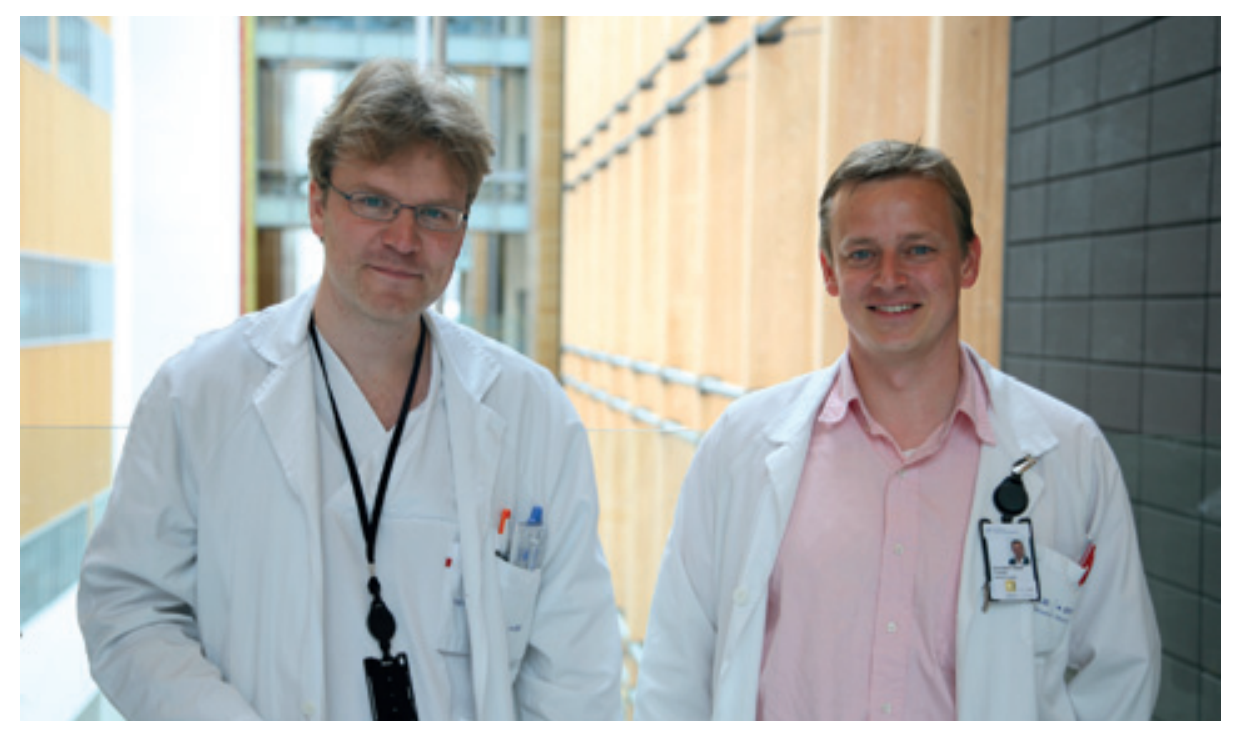

Pål H. Brekke og Arne Didrik Høiseth. Foto Pål H. Brekke

\title{
Hjertemuskelskade ved kolsforverring
}

Myokardskade ved kolsforverring er hyppig og forbundet med økt

dødelighet. Det viser en norsk studie.

Mange kolspasienter har samtidig hjerteog karsykdom, uten at dette nødvendigvis er kjent for pasienten eller for behandlende lege. Ut fra tidligere studier kan mye tyde på at hjertemuskelskade er hyppig under kolsforverringer som fører til sykehusinnleggelse, og at slik skade er forbundet med $ø k t$ dødelighet. Generaliserbarheten av disse funnene har imidlertid vært usikker pga. mulige seleksjonsskjevheter i pasientutvalgene.

- For å unngå seleksjonsskjevheter undersøkte vi sammenhengen mellom hjerteskade og dødelighet $\mathrm{i}$ en uselektert gruppe av 99 kolspasienter innlagt pga. forverring. Siden mange av dem hadde flere innleggelser i inklusjonsperioden, hadde vi målinger fra 219 hendelser tilgjengelig. Disse målingene ble analysert i en utvidet Cox-regresjonsanalyse, sier Arne Didrik Høiseth, lege og stipendiat ved Akershus universitetssykehus.

- Ved en ny og mer sensitiv målemetode påviste vi hjerteproteinet troponin $\mathrm{T}$ hos 97 pasienter, og hele $74 \%$ hadde nivåer over det normale, dvs. over $14 \mathrm{ng} / \mathrm{l}$. I løpet av omtrent to års oppfølgingstid døde $58 \%$ av pasientene. Økende konsentrasjoner av troponin $\mathrm{T}$ var forbundet med redusert langtidsoverlevelse - lett forhøyet konsentrasjon (14-40 ng/l) ga 4,5 ganger økt dødelighet og moderat forhøyet konsentrasjon ( $\geq 40 \mathrm{ng} / \mathrm{l}$ ) ga 8,9 ganger $ø \mathrm{kt}$ dødelighet, etter justering for konfunderende faktorer.

Resultatene innebærer imidlertid ikke at kolspasienter med troponinstigning rutinemessig bør henvises til koronar angiografi.
Troponinstigningen kan ha andre årsaker enn et akutt koronarsyndrom, og så lenge dette ikke er nærmere kartlagt, kan vi ikke anbefale en spesifikk behandling av kolspasienter med troponinstigning. Leger og forskere bør være oppmerksom på mulig hjerteskade hos kolspasienter, og sammenhengen bør undersøkes nærmere slik at pasienter med både kols og hjertesykdom kan tilbys mer helhetlig behandling, sier Høiseth.

\section{Forskning på hjerte- og lungemedisin}

Artikkelen er skrevet av Arne Didrik Høiseth, Anke Neukamm, Bo Daniel Karlsson, Torbjørn Omland, Pål H. Brekke og Vidar Søyseth. Alle arbeider ved Akershus universitetssykehus og er tilknyttet Cardiothoracic Research Group, som ledes av kardiolog og professor Torbjørn Omland, mens det lungefaglige ledes av professor Vidar Søyseth. Brekke disputerte i 2010 med arbeider innenfor området hjertesykdom hos kolspasienter, og Høiseth viderefører hans arbeid i sitt ph.d.-prosjekt.

\section{Erlend T. Aasheim}

erlend.aasheim@legeforeningen.no

Tidsskriftet

\section{Litteratur}

1. Høiseth AD, Neukamm A, Karlsson BD et al. Elevated high-sensitivity cardiac troponin $\mathrm{T}$ is associated with increased mortality after acute exacerbation of chronic obstructive pulmonary disease. Thorax 2011; 66: 775-81.
Ordforklaringer

Kols: Kronisk obstruktiv lungesykdom

Høysensitivitets troponin T: En sensitiv metode for måling av hjerteproteinet troponin T. Metoden har en nedre deteksjonsgrense på $3 \mathrm{ng} / \mathrm{l}$, som er om lag en tidel av hva man ved tidligere metoder kunne måle. Alle større sykehus i landet bruker nå den nye metoden. Anbefalt grense for diagnostisering av hjerteinfarkt er $30 \mathrm{ng} / \mathrm{l}$.

Seleksjonsskjevhet: En systematisk feilkilde i en studie som skyldes utvelgelsen av deltakerne i studien. Dette inntreffer når assosiasjonen mellom eksposisjonen (troponin) og utfallet (overlevelse) er ulik hos dem som deltar og dem som ikke deltar i studien. For det aktuelle temaet er det i tidligere studier ved journalgjennomgang sett retrospektivt på pasienter der troponinnivået er målt på klinisk indikasjon. Disse utvalgte pasientene kan ha annerledes risikoprofil, troponinnivå og overlevelse enn den generelle kolspopulasjonen.

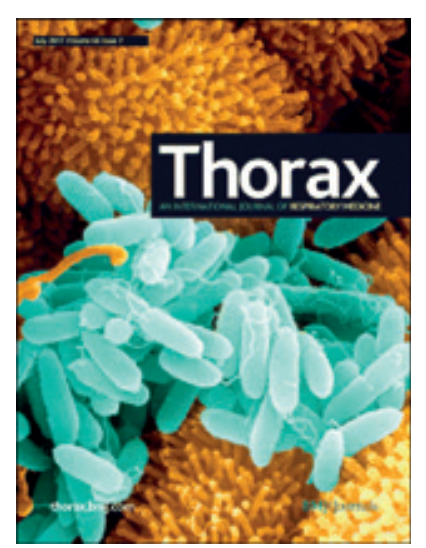

Artikkelen ble 8.6. 2011 publisert på nett og omtalt i en lederartikkel i tidsskriftet Thorax (http://thorax.bmj.com). 